\title{
腐食環境下におけるエポキシ樹脂のキャビテーション・ エロージョン損傷機構*
}

\author{
金東熭**, 津田 健**, 北條英 光*** \\ ** 東京工業大学工学部化学工学科 \\ *** 日本大学生産工学部管理工学科
}

\section{Cavitation Erosion Mechanism of Epoxy Resin in a Corrosive Environment*}

\author{
Dongseop Kim**, Ken Tsuda** and Hidemitsu Hojo*** \\ ** Dept. of Chem. Eng., Fac. of Eng., Tokyo Institute of Technology \\ *** Dept. of Industrial Eng. and Mang., College of \\ Industrial Tech., Nihon University
}

In order to investigate the simultaneous attack behavior of erosion and corrosion of alicyclic epoxy resin, cavitation erosion tests were made by using a magnetostiction vibratory apparatus in pure water and $\mathrm{NaOH}$ solution. The results obtained were as follows: (1) By promoting crack initiation and growth, the erosion damage was accelerated by corrosion. (2) By enlarging surface area and removing corrosive products, the corrosion damage was promoted by erosion. (3) It was also found that the synergistic effect in cavitation erosioncorrosion markedly depended on the relative intensity of cavitation erosion to the concentration of corrosive liquids. (4) Based on the theory of crack propagation, an equation for predicting the damage loss was proposed.

Key words: alicyclic epoxy resin, cavitation erosion test, corrosion, erosion-corrosion, crack propagation

\section{1. 緒言}

高分子材料にも環境条件によっては金属材料と類似の 腐食挙動を示し ${ }^{1)}$ ，これにエロージョン損傷が加わると 腐食とエロージョンとの相互作用によりその損傷速度が 加速される “エロージョン・コロージョン”のよらな現 象が認められる2)。

エロージョン・コロージョン損傷については既に金属 材料を中心にその損傷機構などの面から多くの研究32,4) がなされているが高分子材料の場合, この分野に関する 研究はほとんど行われていない。

前報 ${ }^{2)}$ では材料のエロージョン性の迅速試験法として 慣用されている磁歪振動法を用いて腐食環境下でェポキ

\footnotetext{
* 第 36 回腐食防食討論会（広島, 1989）にて発表

** 干152 東京都目黒区大岡山 2-12-1 (2-12-1, Ookayama, Meguro-ku, Tokyo, 152 Japan)

*** 干 275 千葉県習志野市泉町 1-2-1 (1-2-1, Izumicho, Narashino-shi, Chiba-ken, 275 Japan)
}

シ樹脂のキャビテーション・エロージョン試験を行った ところ, エロージョンだけの場合やコロージョンだけの 場合に比べ損傷量はかなり大きくなり，明らかに腐食は エロージョン損傷を助長することを明らかにした。

本報では, 前報の結果を踏ま光, エポキシ樹脂のキャ ビテーション・エロージョン損傷に及ぼす腐食の影響括 よびその損傷機構についてさらに詳しく検討を加えた。

\section{2. 試験材料および試験方法}

試験装置はすでに報告したものと同じ振動数 $6.5 \mathrm{kHz}$ の磁歪振動法試験装置で, 振幅は $25 \sim 40 \mu \mathrm{m}$ に変化させ た。試験液としては純水と水酸化ナトリウム水溶液（濃 度 7〜20 wt \%) を用い, 環境液の温度は $40^{\circ} \mathrm{C}$ 一定に保 った。試験材料は無水フタル酸で硬化した脂環式ェポキ シ樹脂で, 試験片は直径 $14.3 \mathrm{~mm}$, 厚さ $3 \mathrm{~mm}$ の円板状 のものを使用した。また，損傷の評価には重量変化のほ かに光学顕微鏡や走査型電子顕微鏡等を用いてき裂の進 
展や損傷表面の観察も加えた。

その他の試験条件㔚こび方法はすべて前報と同様であ る。

\section{3. エロージョン・コロージョン損傷}

\section{1 損傷速 度}

本実験で用いた脂環式エポキン樹脂はアルカリ水溶液 中に単純浸せきした場合, 主鎖および架橋部のエステル 結合肪加水分解し切断されることにより，試験片全面が 均一に腐食し溶出していくいわゆる “表面反応型腐食” の形態を示すす1)。

まず，材料のエロージョン・コロージョン損傷を調ベ るために, 振幅を $30 \mu \mathrm{m}$ 一定にし, 純水中およびアルカ リ水溶液中でキャビテーション・エロージョン試験を行 い, 損傷速度之試験時間の関係を示したのが Fig. 1 であ る。純水中での損傷速度はキャビテーション・エロージ ョン損傷に颃いて通常認められる挙動と同様の時間依存 性を示す。すなわち，損傷速度がある時間で極大值を示 した後, 次第に減少しやがて定常状態に達する。一方, アルカリ水溶液中では試験初期を除いてかなり大きな損 傷速度を示して扮り，こ扎㤔腐食效果に起因すると考兄 られる。



Fig. 1 Progressive change in damage rate of epoxy resin in pure water and $10 \mathrm{wt} \%$ $\mathrm{NaOH}$ solution at $40^{\circ} \mathrm{C}$.

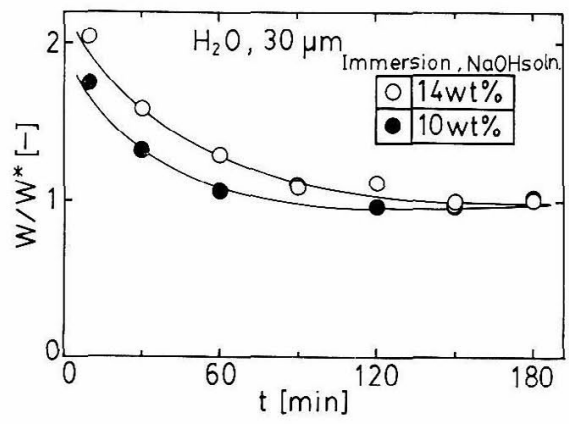

Fig. 2 Effect of corrosion on erosion damage of epoxy resin at $40^{\circ} \mathrm{C}$.

\section{2 エロージョンに及ぼすコロージョンの影響}

前報で述べたよらに腐食環境下でキャビテーション・ エロージョン試験を行った場合，損傷量は試験初期を除 いては純ニロージョンと純コロージョンの各々の損傷量 の単純な和より大きなるのになる2。 これはェャージョ ンとコロージョンとの相互作用に起因すると考学られ る。そこで，腐食がエロージョン損傷に及ぼす影響を調 ベるために，次のよらな実験を行った。まず，試験片を 150 分間ソルカリ水溶液中に浸せきした後取り出し, 純 水中でキャビテーション・エロージョン試験を行った。 その時の損傷量の経時变化を示したのが Fig. 2 である。 縦軸は純エロージョン損傷量すなわち, 試験片をアルカ リ水溶液中に浸さないでそのまま用いた場合の損傷量 $\left(W^{*}\right)$ に対する，あらかじめ浸せきを行った試験片の工 ロージョン損傷量 $(W)$ の比走示すエロージョン試験初 期はあらかじぬ腐食を生じた試験片の損傷が大であり， 時間の経過につれ腐食の影響を受けた部分が取り去られ るため，次第に純エロージョンの損傷量に近付くことが

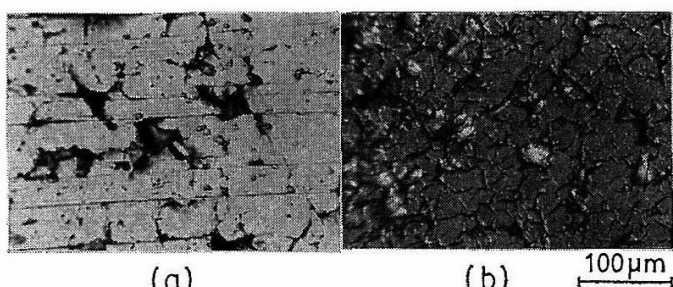

(a)

(b)

Fig. 3 Optical micrographs of eroded surface after $5 \mathrm{~min}$ exposure to cavitation in pure water (a) before testing, (b) after immersing in $10 \mathrm{wt} \% \mathrm{NaOH}$ solution for $150 \mathrm{~min}$ at $40^{\circ} \mathrm{C}$.

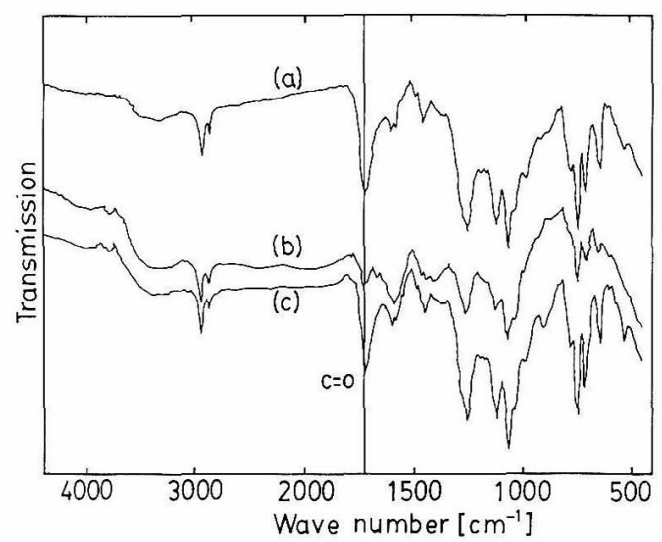

Fig. 4 Variation of IR spectra of resin surface (a) before testing, (b) after $300 \mathrm{~min}$ immersion in $10 \mathrm{wt} \% \mathrm{NaOH}$ solution, (c) after removing corrosive products formed on the surface of (b). 
(a) $\stackrel{\substack{1 \mathrm{~mm} \\ \longrightarrow}}{\stackrel{E}{\longrightarrow}}$

(b)

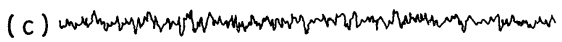

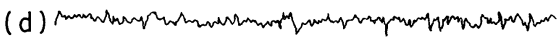

Fig. 5 Progressive change of surface roughness of epoxy resin immersed in $10 \mathrm{wt} \% \mathrm{NaOH}$ solution at $40^{\circ} \mathrm{C}$, (a) before testing, (b) after $90 \mathrm{~min}$ immersion, (c) $180 \mathrm{~min}$, (d) $300 \mathrm{~min}$

わかる。次に, 光学顕微鏡を用いてアルカリ水溶液での 予浸せきの有無による表面状態の違いを比較した。Fig， 3 は, 各条件に执いて 5 分間キャビテーション損傷を与 えた時の損傷表面の顕微鏡写真である。予浸せきを行わ ず腐食の影響がない純水での損傷表面 (a) に比べ，あら かじめ腐食液中に浸せきを行った場合 (b) に执いては多 数のき裂が生じている（このよらなき裂は単純浸せきの 又の場合には見られなかった)。このよらに，エロージョ ンに腐食が加わると材料が腐食の影響を受けき裂が生じ やすくなり損傷量が増大することがわかる。

この原因を調べるために, 全反射法 (ATR 法)による 試験片表面の IR 分析を行った。その吸収スペクトルを Fig. 4 に示す。この図からわかるよらに, 浸せき前に見 られた $1720 \mathrm{~cm}^{-1}$ のエステル結合のピーク1),5) (a)がア ルカリ水溶液中に浸せきを行った場合，(b) のように減 少している。乙か乙, 樹脂の表面層を約 $10 \mu \mathrm{m}$ 削って測 定した結果，(c) のようにもとの樹脂と同様のピークが 現れた。この結果を踏まえ試験片の腐食面を $10 \mu \mathrm{m}$ 程度 研磨した後キャビテーション損傷を与えてみると，その 損傷量および損傷状態は純エロージョンの場合と全く同 様であった。また, Fig. 5 はアルカリ水溶液中に単純浸 せきした場合の試験片の表面粗さの経時的変化を示す が, 時間とともにわずかながら腐食の影響で表面の凹凸 が増していくのがわかる。

以上の結果より，腐食環境下では高分子鎖の切断によ る欠陷や表面の荒れなどがエロージョンを促進すると考 えられる。

\section{3 コロージョンに及ぼすエロージョンの影響}

エロージョンがコロージョンに及ぼす影響としては， まずェロージョンによる表面積の増加が挙げられる。キ

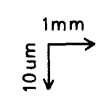

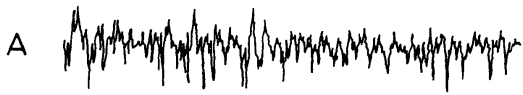

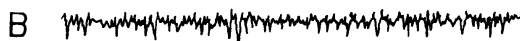

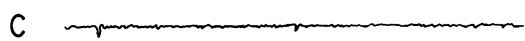

(a)

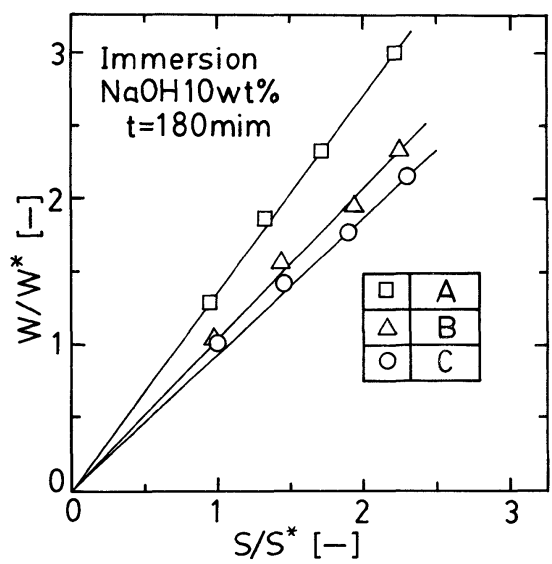

(b)

Fig. 6 Effect of apparent surface area and surface roughness of specimen on corrosion loss in $10 \mathrm{wt} \% \mathrm{NaOH}$ solution at $40^{\circ} \mathrm{C}$, (a) surface roughness of specimen used, (b) test results.

ヤビテーション・エロージョン実験を行った後で, コロ ージョン実験をしたところエロージョンを与えた時間と ともにコロージョン量が増加するのが確認され, 表面の 荒れの増大に伴ら表面積の増加により腐食量が増すこと が予想される。そこで, エメリー紙により表面粗さの異 なる 3 種類の試験板を作り, これから種々の大きさの試 験片を切り出し, キャビテーション・エロージョン・コ ロージョン試験と同一の環境条件下 $(10 \mathrm{wt} \% \mathrm{NaOH}$ 水 溶液, $40^{\circ} \mathrm{C}$ ) で 3 時間の静止浸せき実験を行った。その 結果を Fig. 6 に示す。ここで, 図 (b) 中の A, B, C は 各々図 (a) に示すような粗さを有する試験片について得 られた結果である。同図は大ささ和よび粗さの程度がも っとも小さい試験片（表面積 $S^{*}$ ) の損傷量 $W^{*}$ を基準 とし, 試験片寸法から計算した見かけの表面積 $(S)$ と損 傷量 $(W)$ の関係を示したものであるが，同一表面粗さ の場合は見かけの表面積とともに腐食量が増加し，また 見かけの表面積が同じ場合には表面粗さの増加とともに 腐食量が増加することがわかる。したがって, エロージ 
Table 1 Average damage rate of corrosion and erosion.

\begin{tabular}{c|c|c|c}
\hline \hline $\begin{array}{c}\text { Amplitude } \\
(\mu \mathrm{m})\end{array}$ & $\begin{array}{c}\text { Corrosion rate } \mathrm{R}_{\mathrm{C}} \\
\left(1 \times 10^{-3} \mathrm{mg} / \mathrm{mm}^{2}-\mathrm{h}\right)\end{array}$ & $\begin{array}{c}\text { Erosion rate } \mathrm{R}_{\mathrm{E}} \\
\left(1 \times 10^{-3} \mathrm{mg} / \mathrm{mm}^{2} \cdot \mathrm{h}\right)\end{array}$ & $\mathrm{R}_{\mathrm{E}} / \mathrm{R}_{\mathrm{C}}$ \\
\cline { 1 - 3 } 25 & \multirow{3}{*}{7.8} & 5 & 0.6 \\
\cline { 1 - 3 } & & 39 & 2 \\
\hline 40 & & 36 & 5 \\
\hline
\end{tabular}
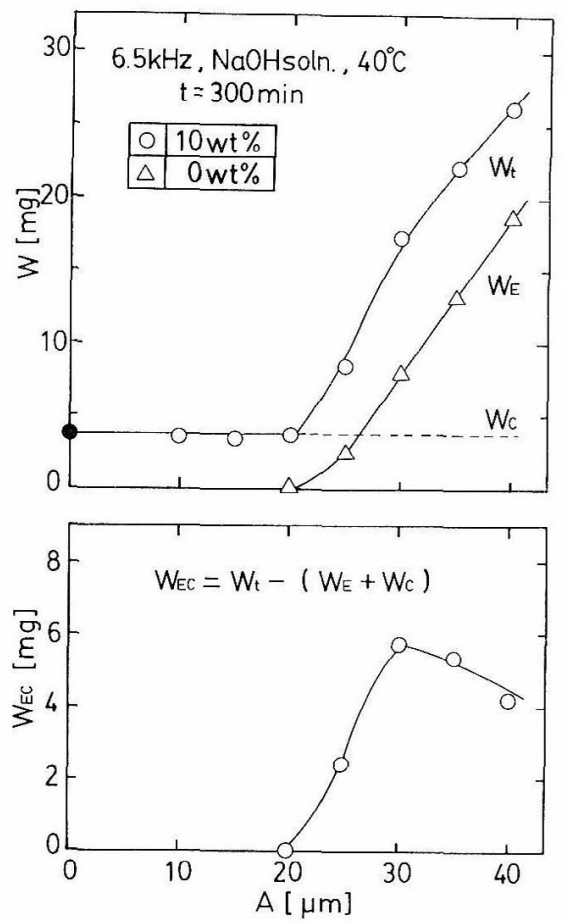

Fig. 7 Effect of amplitude on weight loss and $W_{E C}$.

ヨンによる表面積の增大に伴い，㩦食量が増师すること が推察できる。

また, “表面反応型”之ほ言え, 純コロージョン試験で は材料表面に高粘度の腐食生成物を生ずることが観察さ れた。ところが，振動試験片では腐食生成物は認められ なかった。すなわら，振動により表面の應食生成物が除 去され，これが腐食を促進することも考劣られるので， その影響を見るためにエロージョンの影響が無視でさる 流速域で回転棒実験を行った。その結果, 表面に付着し ている腐食生成物は単純浸せきに比べ，回転棒の方が量 的に少なく，腐食量は多いことが認められた。このこと から, 振動試験片では振動により腐食生成物が除去され， それに上り腐食量が增加することも考えられる。

\section{4 相互作用に及は影響因子}

前節までで，エロージョンとコロージョンとの相互作 用により, 損傷量は各々単独の場合に比べ大となること を述べた。そこでこの相乗効果について検討してみる。

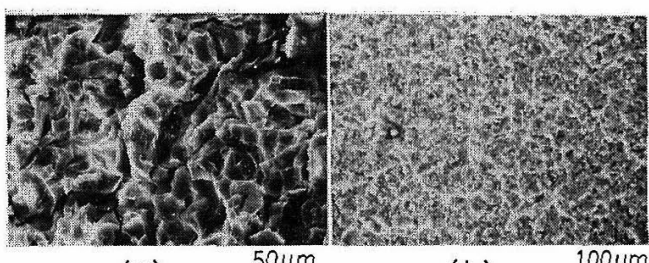

(a)

$50 \mu \mathrm{m}$

(b)

$100 \mu \mathrm{m}$

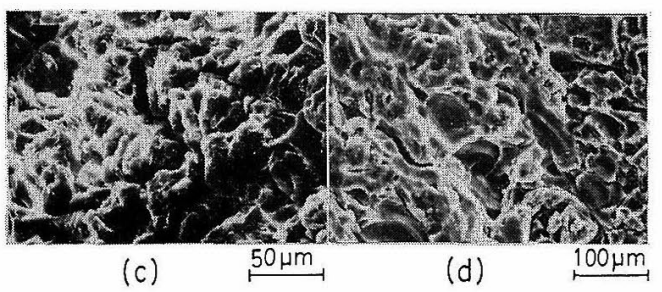

Fig. 8 SEM of specimen surface (a) central region, (b) circumferential region tested in pure water, and (c) central region, (d) circumferential region tested in $10 \mathrm{wt} \%$ $\mathrm{NaOH}$ solution at $40^{\circ} \mathrm{C}$.

腐食環境下でエロージョンを生じるときの損傷量 $W_{t}$ は純エロージョン損傷量 $W_{E}$ (腐食が無視でさる純水で の損傷量）と純腐食量 $W_{C}$ 和よび見か子忛の雨者の相互作 用による相乗㕮果分 $W_{E C}$ の和により

$$
W_{t}=W_{E}+W_{C}+W_{E C}
$$

となり，相乘效果 $W_{E C}$ は

$$
W_{E C}=W_{t}-\left(W_{E}+W_{C}\right)
$$

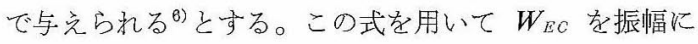
対してプロットレたのが Fig. 7である。W によって異なり，㐫る振幅で最大となる傾向を示してい る。これは Table 1 に示すよら振幅が大きくなると, エロージョン損傷速度が應食速度に比して相対的に大き くなり，損傷はエローションに支配されるためであると 考えられる。一方，振愊が小さくなるとェロージョン効 果が小さくなり，損傷量は和もに腐食に依存することに なる。また，純水括よびアルカリ水溶液中での損傷表面 (試験時間： 5 時間) 孝走查型電子顕微鏡によって観察 した結果をFig. 8 に示す。前報でも述べたよらに損傷面 は, 試験片の中央部の損傷が激しい部分（以下損傷穴と 称する）と荒れの激しい周辺部とに大別できる。損傷穴 での損傷状態には, 環境液の種類による大きな迢いは見 


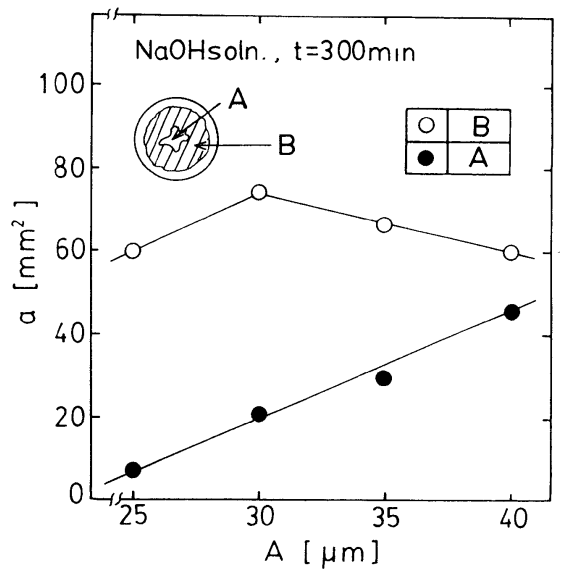

Fig. 9 Effect of amplitude on damage area of central region (A) and circumferential region (B).

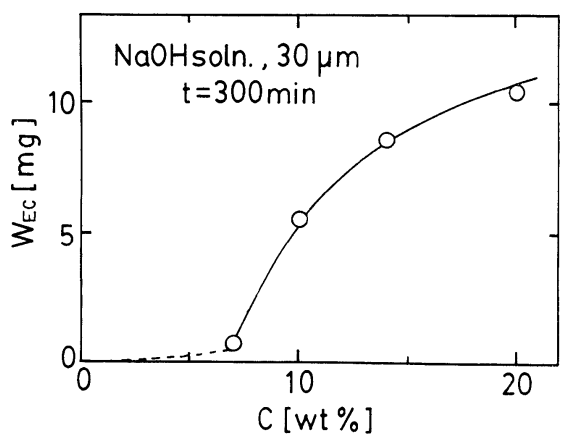

Fig. 10 Effect of concentration of an aqueous $\mathrm{NaOH}$ solution on $W_{\mathrm{EC}}$.

られないが，周辺部ではかなり違いが認められ，とくに 周辺部での腐食効果が大きいことがわかる。Fig. 9 に損 傷穴の表面積（図中のA）扢よび周辺部（図中のB）の 面積を測定した結果を示す。周辺部の面積は $30 \mu \mathrm{m}$ で最 大となりこの振幅で $W_{E C}$ は最大值を示すことになる。

しかし, 環境液濃度の影響については Fig. 7 のよう な傾向とは異なり Fig. 10 に示すように $W_{E C}$ は濃度と ともに増加する傾向が認められた。

\section{4. 損傷機構の考察}

脆性的な材料である脂環式エポキシ樹脂のエロージョ ン損傷は基本的にはき裂の発生と進展により損傷が進行 する。これに腐食が加わると，前節で明らかにしたよう に材料の表面での穴の生成やき裂の発生と進展が促進さ れるためにその損傷量も大きくなる。そこで，き裂につ いて詳細に観察した結果, 穴の底に生じたき裂は腐食環 境下ではより長くかつ鋭くなる ${ }^{2)}$ 。読久取り顕微鏡を用 い, 損傷穴の底に発生したき裂のらち最大のものに注目

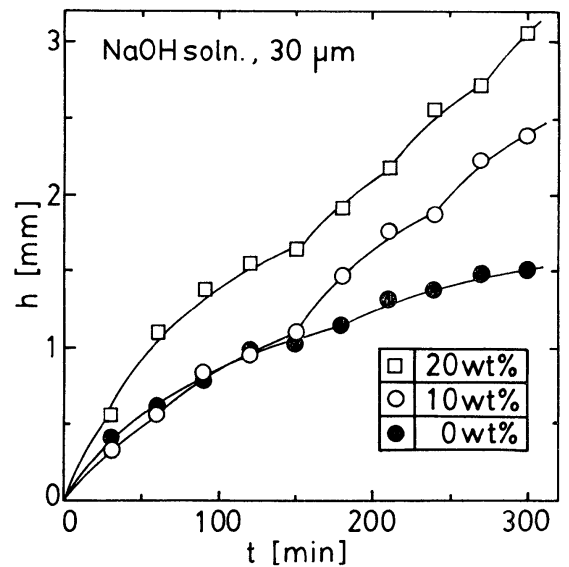

Fig. 11 Progressive change of crack length in pure water and an aqueous $\mathrm{NaOH}$ solution at $40^{\circ} \mathrm{C}$.

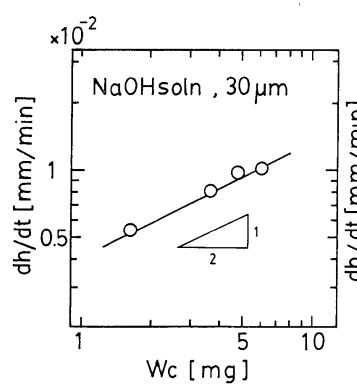

(a)

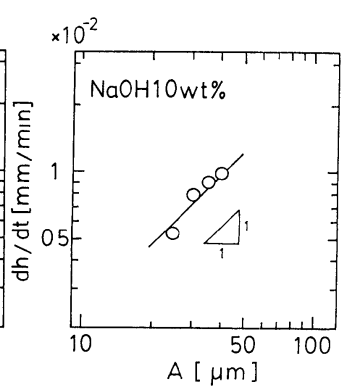

(b)
Fig. 12 Effects of corrosion (a) and amplitude (b) on propagation rate of crack.

し，その長さを経時的に測定した結果を Fig. 11 に示す が，この図からき裂が周期的に速度を変えながら進展し ていく様子がうかがわれ, またき裂の進展速度は環境液 の濃度の増加とともに増していくことがわかる。

腐食環境下に扣けるェロージョン損傷について, 腐食 液と常に接している材料表面にき裂が生じ, それに周期 的に衝撃圧が作用すると考えて検討してみる。

エロージョンを代表するものとして振幅 $A$ を，また コロージョンを代表するものとして $W_{c}$ すなわち， 300 分後のコロージョン損傷量を考光ると, き裂進展速度は

$$
\mathrm{d} h / \mathrm{d} t=f\left(A, W_{c}\right)
$$

のよらに表せる。ここで, 振幅一定のもとでは Fig. 12 (a) に示すように

$$
\mathrm{d} h / \mathrm{d} t \propto\left(W_{c}\right)^{1 / 2}
$$

になる関係が成立している。この図は，Fig. 11 のき裂 進展が平均的には時間とともに直線的に増加して行くと 見なし，その傾きすなわち，き裂の進展速度 $\mathrm{d} h / \mathrm{d} t$ を 300 分後のコロージョン損傷量 $W_{c}$ に対してプロットし 


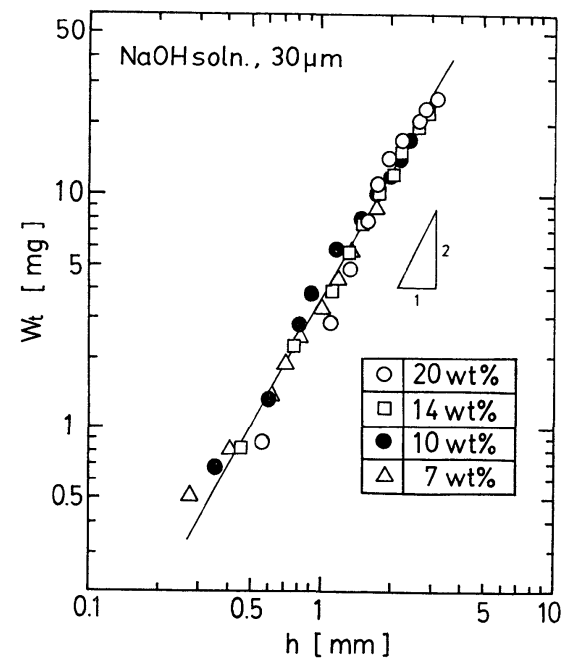

Fig. 13 Relation between total weight loss and crack length in an aqueous $\mathrm{NaOH}$ solution at $40^{\circ} \mathrm{C}$.

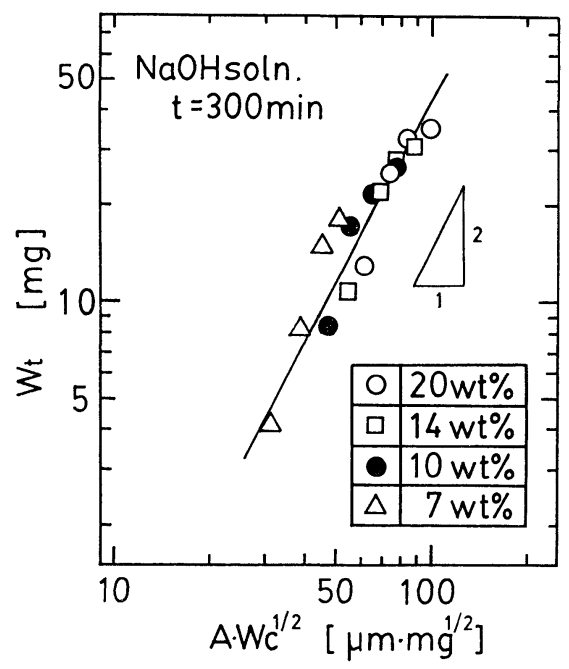

Fig. 14 Relation between total weight loss and $A W_{\mathrm{C}^{1 / 2}}$.

たものである。

また，濃度一定のもとでは, Fig. 12 (b) 飞示すように $\mathrm{d} h / \mathrm{d} t \propto A$

の関係がある。(4) 及び (5) 式より (3) 式は

$$
\mathrm{d} h / \mathrm{d} t \propto A \cdot\left(W_{c}\right)^{1 / 2}
$$

となり，したがって，き裂の長さは

$$
h \propto\left(A \cdot\left(W_{c}\right)^{1 / 2}\right) \cdot t
$$

となる。ここで, また腐食環境下での全損傷量 $W_{t}$ の経
時変化 ${ }^{2)}$ とさ裂長さ $h$ の経時変化 $\left(\right.$ Fig. 11) とから, $W_{t}$ と $h$ の関係は Fig. 13 の上うになり，Wt $h$ のほぼ 2 乗に比例する。したがって，(7) 式は

$$
W_{t} \propto h^{2} \propto\left(\left(A \cdot\left(W_{c}\right)^{1 / 2}\right) \cdot t\right)^{2}
$$

となる。

そこで, $t=300 \mathrm{~min}$ に求いて， $W_{t}$ を $A \cdot\left(W_{c}\right)^{1 / 2}$ に対 してプロットしたのが Fig. 14 である。各条件に和ける 損傷量 $W_{t}$ が $A \cdot\left(W_{c}\right)^{1 / 2}$ の 2 乗に比例し，(8) 式が成立 しているのがわかる。

したがって, 振幅 $A$ 抢よび各環境下に抢ける純腐食 量 $W_{c}$ がわかればその環境下でのエロージョン損傷速度 を予測することが可能となる。

\section{5. 結 言}

脂環式エポキシ樹脂を用いて腐食環境下でキャビテー ション・エロージョン試験を行い，その損傷挙動につい て検討し, 次の結果を得た。

1) エロージョンに及ぼすコロージョンの効果とし て，腐食により樹脂表面の荒れの増大や穴の生成のため き裂の発生や進展が促進され，常に腐食はエロージョン 損傷量を増大させる。

2）コロージョンに及湆すエロージョンの影響はエロ 一ジョンによる表面積の拡大, 腐食生成物の除去など, 損傷を増加させる効果を有する。

3）エロージョンとコロージョンとの相互作用による 相乗効果 $W_{E C}$ はエロージョンとコロージョンの相対的 大きさ（環境液の濃度と振幅）飞依存する。

4）腐食環境下でのキャビテーション・エロージョン に対して簡単なモデルを考光, き裂の進展基づき, 損 傷量を与兄る式を提出した。

\section{文献}

1) 北條英光, 津田 健, 小笠原 強: 強化プラスチ ックス, 34, 49 (1988).

2) 北條英光, 津田 健, 金 東燉：防食技術, 38 , 639 (1989).

3) S. Hogmark, A. Hammarsten \& S. Sonderberg: Proc. 6th Int. Conf. Erosion by Liquid and Solid Impact, 37-1 (1983).

4）松村昌信, 岡 良則：防食技術, 31，67 (1982).

5）小笠原，強，ビーナ・リジャール，北條英光：材 料科学, 22, 280 (1986).

6) 津田 健, 末沢慶忠：化学工学論文集, 1, 213 (1975). 